\title{
Sensory evaluation of "dulce de leche" with coffee and whey using different affective data analysis methods
}

\author{
Avaliação sensorial de doce de leite com café e soro utilizando diferentes metodologias de análise de dados afetivos
}

Larissa Oliveira FERREIRA ${ }^{1 \star}$, Carlos José PIMENTA ${ }^{1}$, Ana Carla Marques PINHEIRO ${ }^{1}$, Patrícia Aparecida Pimenta PEREIRA, Gabriella SANTOS ${ }^{1}$

\begin{abstract}
This study sought to evaluate the acceptance of "dulce de leche" with coffee and whey. The results were analyzed through response surface, ANOVA, test of averages, histograms, and preference map correlating the global impression data with results of physical, physiochemical and sensory analysis. The response surface methodology, by itself, was not enough to find the best formulation. For ANOVA, test of averages, and preference map it was observed that the consumers' favorite "dulce de leche" were those of formulation 1 ( $10 \%$ whey and $1 \%$ coffee) and 2 ( $30 \%$ whey and $1 \%$ coffee), followed by formulation 9 ( $20 \%$ whey and $1.25 \%$ coffee). The acceptance of samples 1 and 2 was influenced by the higher acceptability in relation to the flavor and for presenting higher $\mathrm{pH}, \mathrm{L}^{\star}$, and $\mathrm{b}^{\star}$ values. It was observed that samples 1 and 2 presented higher purchase approval score and higher percentages of responses for the 'ideal' category in terms of sweetness and coffee flavor. It was found that consumers preferred the samples with low concentrations of coffee independent of the concentration of whey thus enabling the use of whey and coffee in the manufacture of dulce de leche, obtaining a new product.

Keywords: milk product; acceptance test; sensory analysis.
\end{abstract}

\section{Resumo}

Este estudo objetivou avaliar a aceitação de doce de leite com café e soro. Os resultados foram analisados por meio de superfície de resposta, ANOVA, teste de médias, histogramas e mapa de preferência, correlacionando os dados de impressão global com resultados de análises físicas, físico-químicas e atributos sensoriais. A metodologia de superfície de resposta, por si só, não foi suficiente para encontrar a melhor formulação. Pela ANOVA, teste de médias e mapa de preferência, observou-se que os doces preferidos pelos consumidores foram os da formulação 1 ( $10 \%$ soro e $1 \%$ café) e 2 (30\% soro e $1 \%$ café) seguidos da formulação 9 ( $20 \%$ soro e $1,25 \%$ café). A aceitação das amostras 1 e 2 foi influenciada, pela maior aceitabilidade em relação ao sabor e por apresentar maiores valores de $\mathrm{pH} \mathrm{L}^{*}($ luminosidade $)$ e $\mathrm{b}^{*}(\mathrm{componente}$ amarelo-azul). Observou-se que as amostras 1e 2 apresentaram maior índice de aprovação de compra e maiores porcentagens de respostas na categoria do ideal quanto à doçura e sabor de café. O doce de leite com café e soro apresentou uma boa aceitação sensorial, constituindo uma alternativa de utilização do soro, bem como o desenvolvimento de um novo produto.

Palavras-chave: produto lácteo; teste de aceitação; análise sensorial.

\section{Introduction}

Dulce de leche is a dairy product, similar to sweetened condensed milk, which is very popular in some South American countries such as Argentina and Uruguay. It is produced by concentrating milk to $68 \%$ total solids by boiling at atmospheric pressure in the presence of added sucrose (approximately 20\%) (ARES; GIMÉNEZ; GÁMBARO, 2006; GIMÉNEZ; ARES; GÁMBARO, 2008a,b; ARES; GIMÉNEZ, 2008). Sodium bicarbonate is added to avoid casein coagulation and to favor the Maillard reaction, responsible for its typical brown color (ARES; GIMÉNEZ; GÁMBARO, 2006; GIMÉNEZ; ARES; GÁMBARO, 2008a,b).

Whey is a greenish-yellow byproduct of the dairy industry obtained by coagulation (GIRALDO-ZUÑIGA et al., 2002). In milk, the whey protein accounts for 80 to $90 \%$ of the total volume entering the manufacturing process and contains about 6 to $6.4 \%$ solids, and about $55 \%$ of the nutrients remain in the original milk whey, namely soluble proteins, lactose, vitamins, and minerals (ALMEIDA; BONASSI; ROÇA, 2001). Whey protein has been used in various food applications due to its functional properties such as gelation, emulsification, solubility, foaming, viscosity, and nutritional value, and it is an excellent source of essential amino acids (MORR; HA, 1993). Countries such as the United States, Australia, Canada, New Zealand, and European Union nations process this byproduct, which is considered a functional ingredient, adding value to the dairy product production line. In Brazil, most cheeses are produced by small companies, which, due to avoid the cost of treating wastewater, use part of this byproduct as animal feed and discard the surplus directly into rivers. Being one of the most extreme examples of dairy industry wastewater, the question is to transform this byproduct from being a problem into a national opportunity (SILVA; BOLIN, 2006).

${ }^{1}$ Ciência dos Alimentos, Universidade Federal de Lavras - UFLA, CEP 3720000, Lavras, MG, Brazil, e-mail: larioliv@hotmail.com

${ }^{*}$ Corresponding author 
The available methods for quality analysis in dairy products involve chemical, physical, microbiological, and sensory tests. Improving the sensory quality of a product should be an industry goal since it contributes to assure product acceptance and leadership the in the market.

Among the available sensory tests to measure consumer preference and acceptability of one or more products, the hedonic scale, the attitude scale, and the Just-About-Right (JAR) scale are the most used. The just-about-right is a scale type that provides information on the intensity of a certain sensory attribute considered as ideal by the consumer. The nine-point structured hedonic scale is probably the most widely used affective methods due to the reliability and validity of its results, as well as its ease of use by the tasters (STONE; SIDEL, 1993).

There are several statistical methods used to analyze the hedonic scale results. The Response Surface Methodology (RSM) is used as a model of consumer response generating predictive equations which correlate consumer response with the variables studied in the process. These predictive equations (models) can be used to optimize processes and to estimate the expected consumer responses to a combinations of factors not directly tested (MOSKOWITZ, 1994).

The results of affective tests are usually assessed using univariate analysis of variance and test of averages (STONE; SIDEL, 1993). Another form of evaluating the hedonic scale results is by analyzing the frequency distribution of the hedonic values obtained for each sample through histograms. Histograms make it possible to visualize the segmentation of the hedonic values of each sample revealing their acceptance and rejection levels and allowing the comparison of the performance of two or more samples which participated in the study (BEHRENS; SILVA; WAKELING, 1999).

With the purpose of analyzing the affective data being taken into account, individual response of each consumer and not the average response of the consumer group that tested the products, the Preference Map technique was developed (MARKETO et al., 1994).

The Preference Map technique uses multivariate statistical analysis to obtain a graphic representation of the acceptance differences among products identifying the individual and their preferences. The Maps can be divided into two categories: internal, used when the analysis includes only the acceptance/ preference data from the affective tests; external, when the descriptive data generated by a team of trained judges and/or the physical and chemical results are also included in the analysis and are associated with the acceptance data (REIS et al., 2006).

Knowing that a certain concentration of a mixture of milk, whey, and sugar results in a "dulce de leche" similar to the traditional one and that new products based on coffee have been launched in the market due to the wide acceptance and popularization of the drink, the aims of this study were to evaluate the acceptance of "dulce de leche" with coffee and whey through acceptance tests in terms of appearance, texture, flavor, and global impression and to evaluate purchase intention, as well as the level of sweetness and coffee flavor using different methods of data analysis, such as the analysis of variance
(ANOVA), Tukey test, histogram frequency, response surface, and external preference map.

\section{Materals and methods}

\subsection{Elaboration of the "dulce de leche"}

The following ingredients were used in the production of the "dulce de leche": pasteurized whole milk (UFLA) crystal sugar produced by the Monte Alegre mill; sodium bicarbonate PA mark Biotec; corn starch manufactured by Santa Amália, sodium citrate PA-ACS, Synth; instant coffee (extra strong) manufactured by Nestlé ; and milk whey originated from the production of the Minas Frescal cheese. The "dulce de leche" was elaborated following the technology proposed by Martins and Lopes (1981).

The following ingredients were used in the production of the cheese: pasteurized whole milk (UFLA) and 50\% calcium chloride and coagulum manufactured by Hansen Indústria $e$ Comercio Ltda. After the coagulation of the milk, the cheese (casein) was separated from the whey. The whey was filtered through a sieve for the complete separation of casein. Next, it was wrapped in polyethylene plastic bags and stored under refrigeration to be used in the dulce de leche" production.

Before beginning the production of the "dulce de leche", the acidity of the milk was reduced to $1 \mathrm{~g}$ of lactic acid. $\mathrm{L}^{-1}$, and the acidity of whey was reduced to $0.8 \mathrm{~g}$ de lactic acid. $\mathrm{L}^{-1}$ using sodium bicarbonate.

The equipment used to produce the "dulce de leche" consisted of a lidless pot with a working capacity of $20 \mathrm{~L}$ of milk. The mixture (milk + whey) was placed in the equipment, and after heating it, sugar $(20 \%)$, sodium citrate $(0.08 \%)$, and starch $(0.5 \%)$ was added. The different formulations of the "dulce de leche" were cooked until they reached a soluble solid level of $\pm 71 \%$. After reaching the end point, the instant coffee, which was previously diluted in hot water, was added at a ratio of 1:1 (coffee:water). Coffee, sugar, sodium citrate, and starch were added according to the desired amount of mixture (milk + whey). After the addition of coffee, the "dulce de leche" was bottled in glass jars and stored in cardboard boxes for the analyses.

\subsection{Experimental design}

A central composite rotational design was used to analyze the influence of the process variables on the variable response. The experiments were performed according to a complete factorial experimental design $2^{2}($ level \pm 1 ) with the addition of central points (level 0 ) and axial points (levels \pm 1.41 ). The axial points $( \pm \alpha)$ are used for enlargement of the lineal model making it quadratic. The value of $\alpha$ is a function of the number of independent variables $(\mathrm{k})$ and is defined by the Equation 1 (BARROS NETO; SCARMINIO; BRUNS, 1995).

$\alpha=\left(2^{k}\right)^{1 / 4}$

Since there are two independent variables, the value of $a$ is 1.41 
The codified and real levels of the studied factors are presented in Table $1\left(\mathrm{x}_{1}: \%\right.$ of substitution of milk by whey and $\mathrm{x}_{2}: \%$ of coffee addition). 11 assays were carried out: four factorial (combinations among levels \pm 1 ), three central (three variables in the level 0 ) and four axial assays (one variable in the level \pm 1.41 and one in the level 0 ).

The variation ranges between the inferior and superior limits of each independent variable were established based on literature data and previously performed preliminary tests.

\subsection{Sensory evaluation}

The analysis was conducted with 60 "dulce de leche" and coffee consumers of varied ages, who were students, professors, and employees of the Federal University of Lavras. They were were offered approximately $10 \mathrm{~g}$ of each formulation in disposable cups codified with three-digit numbers.

The samples presentation order was balanced in two sessions according to Wakeling and McFie (1995). In the first session, six samples were presented; in the second session, the other five were presented. Unflavored, dry crackers and water were supplied to assist in cleansing the palate between samples. The test was conducted in the afternoon in the Sensorial Analysis Laboratory at the Federal University of Lavras using individual booths and white light.

A nine-point structured hedonic scale $(1=$ disliked and $9=$ liked extremely) was used in the acceptance test of the "dulce de leche" for the evaluation of the appearance, flavor, texture, and global impression attributes according to Stone and Sidel (1993).

The purchase intention of the product was evaluated using a five-point structured scale, $(1=$ certainly would not buy and 5 = certainly would buy) according to Stone and Sidel (1993).

The just-about-right scale was also used, according to Minim (2006), for the evaluation of sweetness and coffee flavor attributes. A seven-point mixed structured scale was used, in which, $(+3)$ - represented sweetness or coffee flavor much stronger than the ideal; (0) - ideal; (-3) - represented sweetness or coffee flavor less strong than the ideal.

Table 1. Central composite design $\left(2^{2}\right)$ with 2 independent variables, 3 replicates at the central point (c), and 4 axial points.

\begin{tabular}{rlccl}
\hline \multirow{2}{*}{ Tests } & \multicolumn{2}{c}{ Variables coded } & \multicolumn{2}{c}{ Real variables } \\
\cline { 2 - 5 } & $\mathrm{x}_{1}^{*}$ & $\mathrm{x}_{2}^{* *}$ & $\mathrm{X}_{1}(\%)$ & $\mathrm{X}_{2}(\%)$ \\
\hline 1 & -1 & -1 & 10 & 1 \\
2 & +1 & -1 & 30 & 1 \\
3 & -1 & +1 & 10 & 1.5 \\
4 & +1 & +1 & 30 & 1.5 \\
5 & -1.41 & 0 & 5.9 & 1.25 \\
6 & +1.41 & 0 & 34.4 & 1.25 \\
7 & 0 & -1.41 & 20 & 0.9 \\
8 & 0 & +1.41 & 20 & 1.60 \\
9 & 0 & 0 & 20 & 1.25 \\
10 & 0 & 0 & 20 & 1.25 \\
11 & 0 & 0 & 20 & 1.25 \\
\hline
\end{tabular}

${ }^{*} \mathrm{x}_{1}$ : \% of substitution of milk by whey and ${ }^{* *} \mathrm{x}_{2}: \%$ of coffee addition

\subsection{Physicochemical analysis}

\section{Color analysis}

The $\mathrm{L}^{*}, \mathrm{a}^{*}$ and $\mathrm{b}{ }^{*}$ values were determined using a colorimeter (Minolta, model CR 400), working with $\mathrm{D}_{65}$ (daylight) and using the CIElab standards.

\section{Evaluation of instrumental texture profile (TPA)}

The Texture Profile Analysis (TPA) was performed using the Stable Micro Systems texturemeter (model TA.XT2i). The samples were evaluated in triplicate in the glass jar $(250 \mathrm{~g}$ capacity) in which they were packed. The following parameters were adopted for the tests: pre-test speed: $2.0 \mathrm{~mm} / \mathrm{second}$; speed tests: $1.0 \mathrm{~mm} /$ second; post-test speed: $2.0 \mathrm{~mm} / \mathrm{second}$; distance: $10.0 \mathrm{~mm}$; time: 0.5 seconds; contact force: $5.0 \mathrm{~g}$; and probe: $20.0 \mathrm{~mm}$ (P20) acrylic cylinder.

\section{Soluble solids}

The concentration of soluble solids was determined using refractometer readings at $20^{\circ} \mathrm{C}$, according to Instituto Adolfo Lutz (IAL, 1985).

$p H$

Was determined using the electroanalytical (potentiometric) method in a Tecnal Tec 3MP pHmeter, according to Instituto Adolfo Lutz (1985).

Acidity

Was determined by titrations with $0.1 \mathrm{~N}$ sodium hydroxide $(\mathrm{NaOH})$ solution using phenolphthalein as the indicator. The results were expressed as percentage of compounds with acid character, such as lactic acid, according to the methodology proposed by Pereira et al. (2000).

All analyses were carried out in triplicate.

\section{Analyses results}

\subsection{Response surface analysis}

To verify the effects of the independent variables (percentage of milk substitution for whey and percentage of coffee addition) and their interactions on the attributes (appearance, flavor, texture, and global impression), the $t$ test was conducted to assure the validity of those effects within a level of established significance (p). The data processing was done using the Statistics for Windows 5.0 (STATSOFT..., 1995) software.

\subsection{ANOVA analysis and test of averages}

The data regarding the acceptance of the samples were evaluated using variance analysis (ANOVA), followed by the test of averages (Tukey, $\mathrm{p}<0.05$ ). The average of the acceptance scores of the three repetitions (assays 9, 10, and 11) in the central point was obtained since they present the same formulation and there is no need to compare the average of the same treatments. 
This procedure (calculation of the average) was performed for all analyses cited below. The variance analyses and the test of averages were conducted using the Sisvar software (FERREIRA, 2000).

\subsection{Frequency histogram analysis}

Based on the results of the test with just-about-right scale (seven-point mixed structured scale) and purchase intention (five-point structured scale), frequency histograms were constructed.

\subsection{Preference mapping analysis}

With the purpose of analyzing the acceptance data taking into account each individual consumer response and not the average response of the group and to correlate them with the sensorial analyses (appearance, flavor, and texture), physical (color and instrumental texture) and physiochemical data (soluble solids, $\mathrm{pH}$, and titratable acidity), the acceptance data were also analyzed by the vectorial External Preference Map (EPM) (SCHLICH, 1995) methodology using the R software (R DEVELOPMENT..., 2007).

This study was approved by the Ethics Committee of the University President Antônio Carlos (\# 670/2010), Barbacena, MG, Brazil.

\section{Results and discussion}

In the statistical analysis using response surface methodology, the studied factors, percentage of substitution of milk for whey, coffee addition percentage, and whey x coffee interactions did not influence significantly $(p \geq 0.05)$ the acceptance of the sensory attributes (appearance, flavor, texture, and global impression) evaluated by the consumers (Table 2).

Therefore, under the studied conditions, it was not possible to obtain a mathematical model for appearance, flavor, texture, and global impression variables or generate a surface for these variables. Hence, the appearance, flavor, texture, and global impression data were analyzed using the Analysis of Variance (ANOVA) and Tukey average test.

The variance analysis showed significant difference $(p \geq 0.05)$ in the acceptance of the samples in terms of flavor, texture, appearance, and global impression of the "dulce de leche" (Table 3).

According to Moskowitz (1994), the Response Surface Methodology (RSM) is used to model the consumer responses generating predictive equations with correlations between consumer response and process variables. The Tukey test is used to test any contrast between two means. It is a very versatile test, but it does not allow comparison between different groups (BANZATTO; KRONKA 2006). Therefore, the analysis using the response surface methodology was not statistically significant because the differences were calculated based on the effects that their independent variables or factors have on the responses since the Tukey test calculates the differences between two tests without evaluating the effect each independent variable may have on the studied response.

In general, the average scores fell between 7 and 8 ("moderately liked" and "liked a lot", respectively) in the hedonic scale.

With regard to the attribute appearance, sample $9(20 \%$ whey and $1.25 \%$ coffee), which obtained the highest score

Table 2. Estimated effect, pure error, coefficient $t$, and statistical significance for each factor for the sensory attributes: appearance, flavor, texture, and overall impression.

\begin{tabular}{|c|c|c|c|c|c|}
\hline $\begin{array}{l}\text { Sensorial } \\
\text { Attributes }\end{array}$ & Factor & Effect & $\begin{array}{l}\text { Pure } \\
\text { Error }\end{array}$ & $\mathrm{t}$ & $\mathrm{P}$ \\
\hline \multirow[t]{6}{*}{ Appearance } & Mean & 7.82 & 0.17 & 47.30 & $0.00^{* *}$ \\
\hline & Whey (L) & 0.11 & 0.20 & 0.52 & 0.62 \\
\hline & Whey (Q) & -0.27 & 0.24 & -1.12 & 0.31 \\
\hline & Coffee (L) & -0.13 & 0.20 & -0.63 & 0.56 \\
\hline & Coffee (Q) & -0.38 & 0.24 & -1.58 & 0.18 \\
\hline & Whey $\times$ Coffee & 0.045 & 0.29 & 0.16 & 0.88 \\
\hline \multirow[t]{6}{*}{ Flavor } & Mean & 7.38 & 0.16 & 45.43 & $0.00^{\star *}$ \\
\hline & Whey (L) & 0.06 & 0.20 & 0.29 & 0.78 \\
\hline & Whey (Q) & -0.10 & 0.24 & -0.43 & 0.68 \\
\hline & Coffee (L) & -0.45 & 0.20 & -2.28 & 0.07 \\
\hline & Coffee (Q) & -0.09 & 0.24 & -0.41 & 0.70 \\
\hline & Whey $\times$ Coffee & 0.14 & 0.28 & 0.50 & 0.64 \\
\hline \multirow[t]{6}{*}{ Texture } & Mean & 7.62 & 0.31 & 24.76 & $0.00^{\star *}$ \\
\hline & Whey (L) & 0.18 & 0.38 & 0.47 & 0.66 \\
\hline & Whey (Q) & -0.40 & 0.45 & -0.90 & 0.41 \\
\hline & Coffee (L) & -0.16 & 0.38 & -0.43 & 0.69 \\
\hline & Coffee (Q) & -0.26 & 0.45 & -0.60 & 0.58 \\
\hline & Whey $\times$ Coffee & 0.41 & 0.53 & 0.77 & 0.48 \\
\hline \multirow[t]{6}{*}{$\begin{array}{c}\text { Global } \\
\text { impression }\end{array}$} & Mean & 7.55 & 0.22 & 33.90 & $0.00^{* *}$ \\
\hline & Whey (L) & 0.09 & 0.27 & 0.32 & 0.76 \\
\hline & Whey (Q) & -0.27 & 0.33 & -0.84 & 0.44 \\
\hline & Coffee (L) & -0.21 & 0.27 & -0.78 & 0.47 \\
\hline & Coffee (Q) & -0.13 & 0.33 & -0.41 & 0.70 \\
\hline & Whey $\times$ Coffee & 0.01 & 0.39 & 0.01 & 0.99 \\
\hline
\end{tabular}

Table 3. Average scores assigned by the panelists for appearance, flavor, texture, and global impression ${ }^{1}$.

\begin{tabular}{lcccc}
\hline \multirow{2}{*}{ Tests } & \multicolumn{4}{c}{ Sensorial attributes } \\
\cline { 2 - 5 } & Appearance & Texture & Flavor & Global impression \\
\hline 1 & $7.73^{\mathrm{ab}}$ & $7.88^{\mathrm{a}}$ & $7.82^{\mathrm{a}}$ & $7.73^{\mathrm{a}}$ \\
2 & $7.77^{\mathrm{ab}}$ & $7.68^{\mathrm{a}}$ & $7.67^{\mathrm{a}}$ & $7.82^{\mathrm{a}}$ \\
3 & $7.50^{\mathrm{bcd}}$ & $7.10^{\mathrm{b}}$ & $7.02^{\mathrm{e}}$ & $7.28^{\mathrm{b}}$ \\
4 & $7.63^{\mathrm{abc}}$ & $7.72^{\mathrm{a}}$ & $7.15^{\mathrm{cde}}$ & $7.38^{\mathrm{b}}$ \\
5 & $7.30^{\mathrm{cd}}$ & $6.80^{\mathrm{c}}$ & $7.05^{\mathrm{de}}$ & $7.02^{\mathrm{d}}$ \\
6 & $7.48^{\mathrm{bcd}}$ & $7.00^{\mathrm{bc}}$ & $7.23^{\mathrm{bcd}}$ & $7.13^{\mathrm{cd}}$ \\
7 & $7.33^{\mathrm{cd}}$ & $7.03^{\mathrm{bc}}$ & $7.32^{\mathrm{bc}}$ & $7.20^{\mathrm{bcd}}$ \\
8 & $7.23^{\mathrm{d}}$ & $7.07^{\mathrm{bc}}$ & $6.97^{\mathrm{e}}$ & $7.23^{\mathrm{bc}}$ \\
9 & $7.93^{\mathrm{a}}$ & $7.75^{\mathrm{a}}$ & $7.42^{\mathrm{b}}$ & $7.65^{\mathrm{a}}$ \\
$\mathrm{CV}(\%)$ & 9.14 & 6.55 & 4.97 & 5.00 \\
\hline
\end{tabular}

${ }^{1}$ Means in columns followed by same letter do not differ statistically $(\mathrm{p}<0.05)$. $\mathrm{CV} \%=$ coefficient of variation. 
average (7.93), was considered statistically similar to samples 1 ( $10 \%$ whey and $1 \%$ coffee), 2 (30\% whey and $1 \%$ coffee), and 4 (30\% whey and $1.5 \%$ coffee).

As for the texture, samples 1 ( $10 \%$ whey and $1 \%$ coffee), 2 (30\% whey and $1 \%$ coffee), 4 (30\% whey and $1.5 \%$ coffee), and 9 (20\% whey and $1.25 \%$ coffee) did not present significant difference amongst themselves; therefore, they differed from all other samples presenting higher average acceptance values.

With regard to the flavor attribute, samples $1(10 \%$ whey and $1 \%$ coffee) and 2 (30\% whey and $1 \%$ coffee), whose acceptance averages were 7.82 and 7.67 , respectively, did not present significant difference amongst themselves; however they stood out significantly ( $\mathrm{p} \geq 0.05)$ from the others.

The average global impression values indicate that samples 1 ( $10 \%$ whey and $1 \%$ coffee), 2 (30\% whey and $1 \%$ coffee), and 9 ( $20 \%$ whey and $1.25 \%$ coffee) were the best, with scores of 7.73 , 7.82 , and 7.65, respectively.

It was observed that samples 1 ( $10 \%$ whey and $1 \%$ coffee) and $2(30 \%$ whey and $1 \%$ coffee $)$ stood out in terms of sensory attributes (appearance, texture, flavor, and global impression).

For the analysis of the data obtained from the just-aboutright scale (Figure 1) and purchase intention (Figure 2), frequency histograms constructed.
It can be observed that sweetness was considered ideal for most of the formulated products since they presented higher frequency of 0 score ("ideal”). Sample 2 (30\% whey and $1 \%$ coffee) received the highest percentage $(63 \%)$ of 0 score ("ideal"), followed by sample 1 ( $10 \%$ whey and $1 \%$ coffee) $(62 \%)$ (Figure 1). These results corroborate with the results obtained in the acceptance test, in which a significantly higher acceptance is observed for samples 1 and 2 for the attributes evaluated.

Most formulations received higher frequency of 0 score ("ideal") indicating an ideal coffee flavor. Sample 1 (10\% whey and $1 \%$ coffee) received the highest percentage $(52 \%)$ of 0 score ("ideal"), followed by sample 2 (30\% whey and $1 \%$ coffee) ( $48 \%)$ and sample 9 (20\% whey and $1.25 \%$ coffee) (48\%) (Figure 1).

Sample 8 (20\% whey and $1.6 \%$ coffee) received the lowest score average for the attribute flavor, which can be explained by the just-about-right scale, since the sample presented the lowest number of 0 scores considered (ideal) and higher number of scores between 1 and 3 for the attributes sweetness and coffee flavor thus indicating above the ideal sweetness and coffee flavor stronger than the ideal.

Sample 1 (10\% whey and $1 \%$ coffee) presented the highest purchase intent score since $80 \%$ of the tasters would certainly or possibly buy the product. Sample 2 (30\% whey and $1 \%$ coffee) presented $75 \%$ of purchase intent followed by sample 9 (20\% whey and $1.25 \%$ coffee), with $73 \%$, showing that these
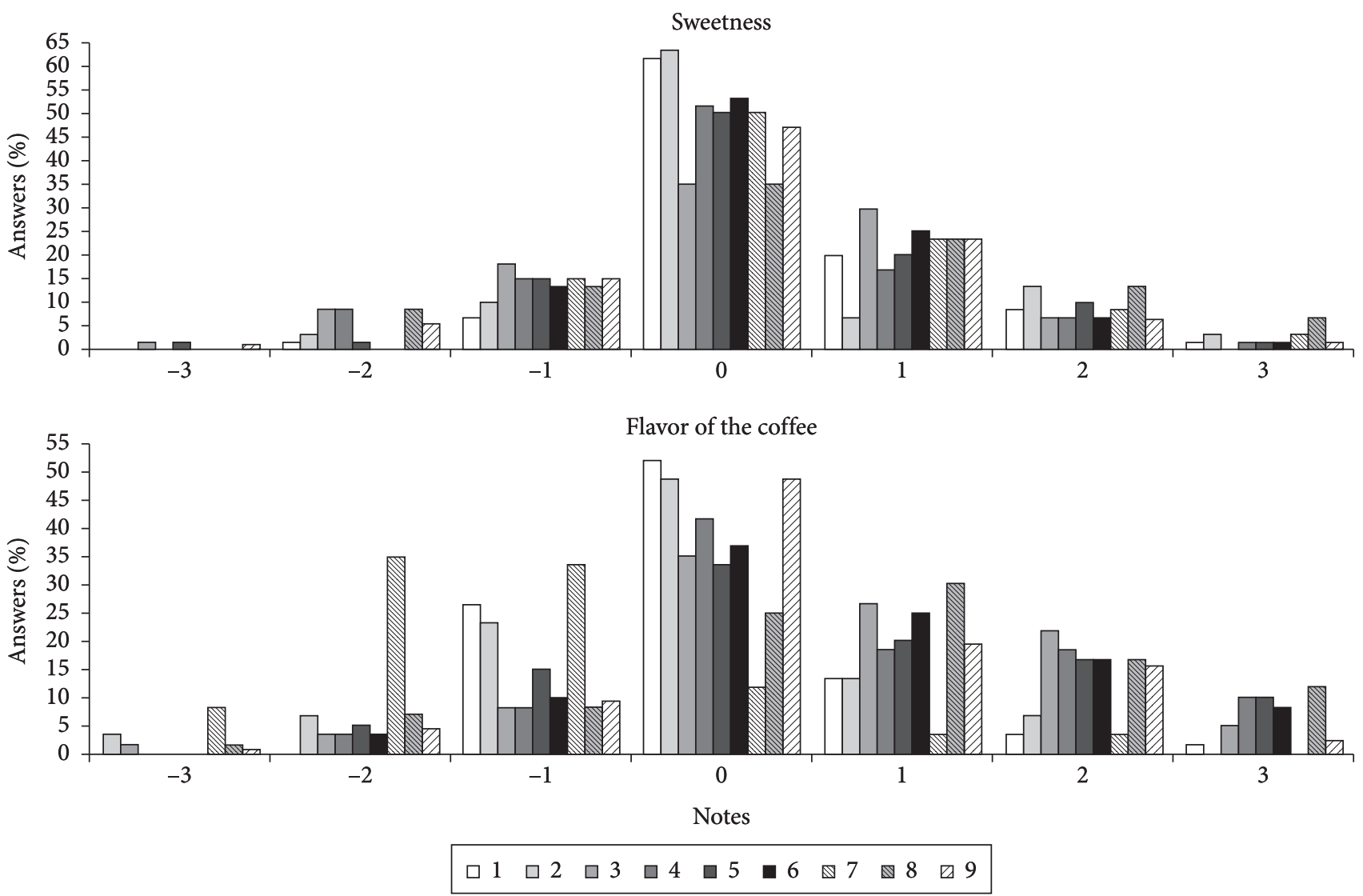

Figure 1. Histogram distribution of sweetness and flavor of the coffee scores. $(-3=$ Much less sweet $/$ strong than the ideal, ideal $=0,+3=$ much sweeter/stronger than the ideal). 
formulations were well accepted and that if available in the market they would possibly be bought (Figure 2).

It can be observed that samples 1 (10\% whey and $1 \%$ coffee) and 2 (30\% whey and $1 \%$ coffee), besides standing out in all of the sensorial attributes of flavor, texture, appearance, and global impression, were the samples that presented the highest purchase intent score and the highest response percentages in the just-about-right scales for sweetness and coffee flavor. The samples that presented the lowest acceptance averages were samples 5 and 8 . Sample 5 presented the lowest whey concentration (5.9\%) and sample 8 the highest coffee concentration (1.6\%). It is noteworthy that samples 1 and 2 did not present a significant difference $(p>0.05)$ in terms of appearance acceptance, texture, flavor, and global impression; therefore, it is can be said that the whey concentration did not influence the acceptance of the samples since those samples presented 10 and $30 \%$ whey, respectively, which is in accordance with the studies of Machado (2005); Dias, Corrente and Dias (2008); and Madrona et al. (2009).

Machado (2005), studying the acceptance of "dulce de leche" with addition of different whey and modified corn starch concentrations, reported that the higher the whey percentage, independent of the starch percentage and storage time, the higher the appearance, purchase intention, color, consistency, and the overall impression of the "dulce de leche" formulations.

Evaluating the acceptance of "dulce de leche" produced with addition of whey, Dias, Corrente and Dias (2008) observed that the formulation produced without whey addition and that produced with addition of $20 \%$ whey in substitution for whole milk presented practically the same taster preference results.

Madrona et al. (2009) studied the effect of the addition of whey on the sensory quality of "dulce de leche" and concluded that replacing it with $50 \%$ fresh whey or powder showed a less cloying flavor, higher purchase intent, and consistency closer to the "ideal" score. In general, the authors observed that the use of fresh whey does not influence the sensory quality of "dulce de leche" is a great alternative to reuse of this by product.

In addition to the analysis of the data through optimization (response surface), ANOVA and test of averages, the multivariate analysis called external preference mapping was performed in order to evaluate the global impression acceptance of the samples considering the individual evaluation of each taster and to correlate this preference with the data from appearance and acceptance, texture, flavor and those of physical (color and instrumental texture) and physiochemical (soluble solids, $\mathrm{pH}$ and acidity) analyses.

The data analysis through multivariate analysis generated a preference map based on global aspect data (Figure 3) and the correlation circle (Figure 4), which shows the correlation of the global impression data with the sensorial, physical, and physiochemical results.

The map generated in this study explains $70.43 \%$ of the variability in its first two components.

The spatial separation of the samples plotted on the preference map (Figure 3 ) showed that samples 1 ( $10 \%$ whey and $1 \%$ coffee) and 2 (30\% whey and $1 \%$ coffee) were the favorite in terms of global impression since about 60 to $70 \%$ of the tasters gave them acceptance scores above the general average (7.4).

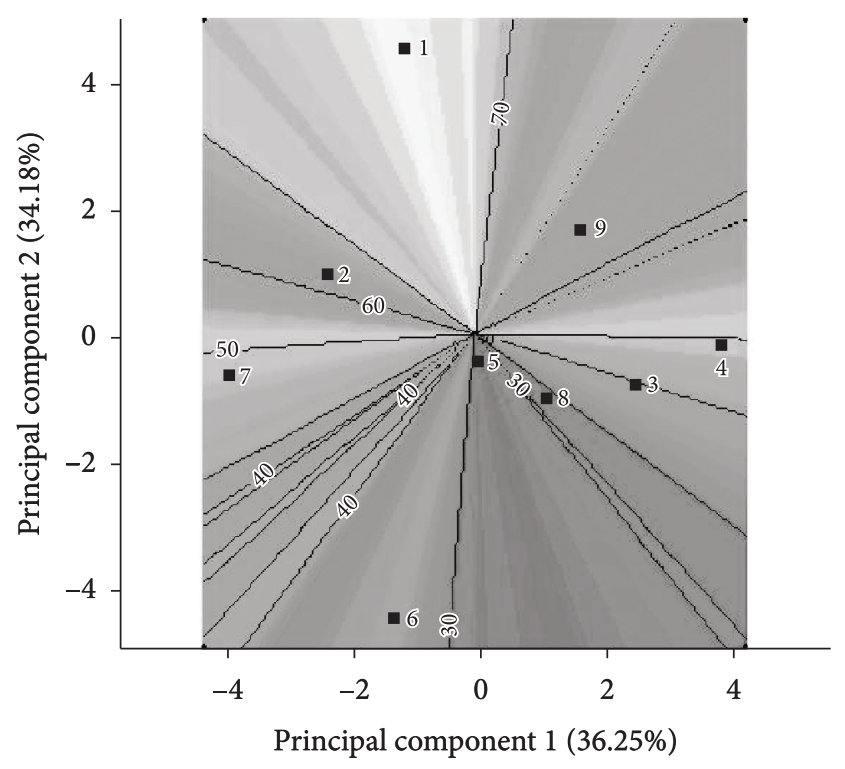

Figure 3. Map of preference global impression of the samples.

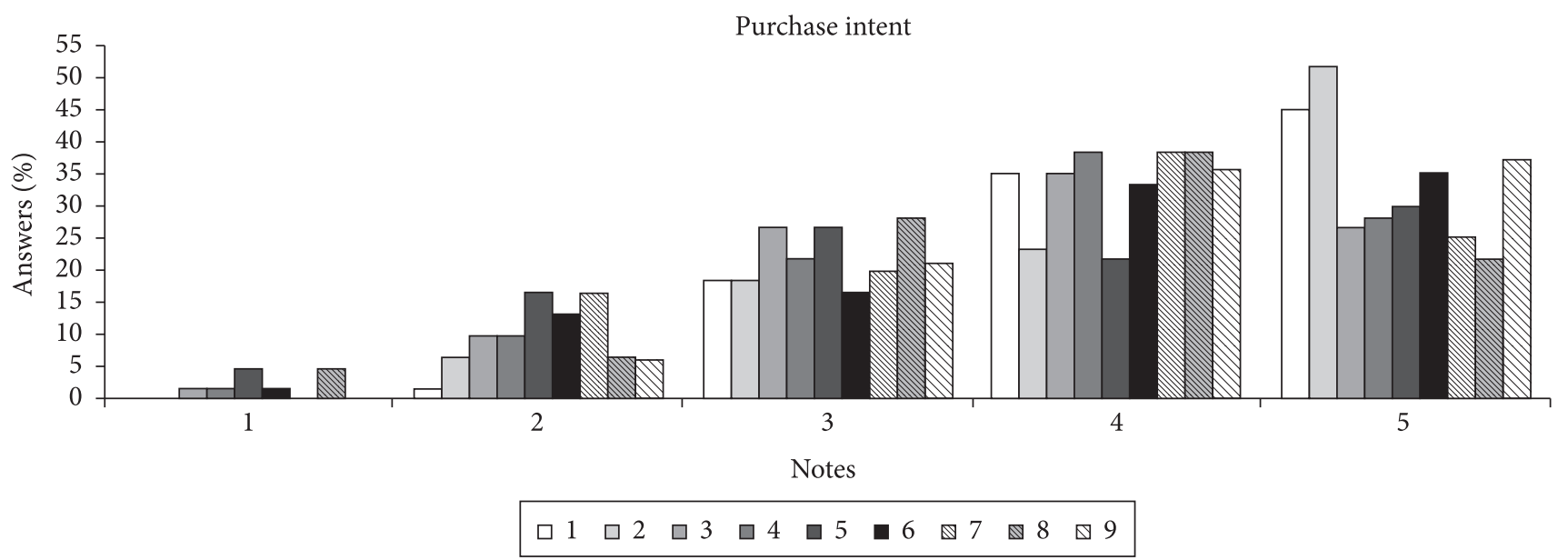

Figure 2. Histogram distribution of purchase intent scores. ( 1 = certainly would not buy, 5 = certainly would buy). 
It can be seen in Figure 3 that the samples 5 (5.9\% whey and $1.25 \%$ coffee) and 8 ( $20 \%$ whey and $1.6 \%$ coffee) were those with the lowest acceptance percentage in terms of global impression since about $30 \%$ of the tasters gave those samples acceptance scores above the general average (7.4). Thus, lower percentage of consumers was found regarding the number of scores given to samples 5 and 8 , which indicates the lowest consumer preference for these samples. These results are in agreement with the results found in the test of averages because samples 5 and 8 were those that presented the lowest global impression averages.

Based on the Preference Map (PM), in terms of acceptance (Figure 3), higher percentage of consumers was observed involving samples 1 (10\% whey and $1 \%$ coffee) and $2(30 \%$ whey and $1 \%$ coffee), followed by sample 9 (20\% whey and $1.25 \%$ coffee), which indicates stronger consumer preference for these samples.

It can be seen in Figure 4 that $70.43 \%$ of the variability among the samples, explained by the first and second main components, were mainly due to the variables hardness, soluble solids, gumminess, acceptance in relation to the flavor, $\mathrm{pH}, \mathrm{L}^{*}$ value, $\mathrm{b}^{\star}$ value, and adhesiveness, which presented vectors with higher projections in the first and the second main components.
The individual characteristics of each sample can be found by superimposing Figure 4 graph on Figure 3 graph. Figure 3 shows that samples 1 and 2 are in the fourth quadrant, which includes flavor, $\mathrm{pH}, \mathrm{L}$ * (lightness), and $\mathrm{b}$ * (yellow-blue component), and the first quadrant contains sample 9 close to the hardness, gumminess, and soluble solids. Therefore, the correlation circle (Figure 4) indicated that the global impression of samples 1 (10\% whey and $1 \%$ coffee) and 2 (30\% whey and $1 \%$ coffee) was mainly influenced by the higher acceptability in terms of flavor and for presenting higher $\mathrm{pH}$ and $\mathrm{L}^{*}$ and $\mathrm{b}^{*}$ values. The acceptance of sample 9 (20\% whey and $1.25 \%$ coffee) was characterized mainly by the higher hardness and gumminess and higher of levels soluble solid. In the case of samples 5 (5.9\% whey and $1.25 \%$ coffee) and 8 (20\% whey and $1.6 \%$ coffee), it is noticed that none of the sensorial attributes nor the analyzed variables influenced the acceptability of these samples.

Vectors next to each other indicate descriptors that possibly present high correlation amongst themselves. Therefore, analyzing Figure 4, it is possible to suggest a positive correlation among gumminess and soluble solids, texture, and cohesiveness and a negative correlation between hardness and adhesiveness.

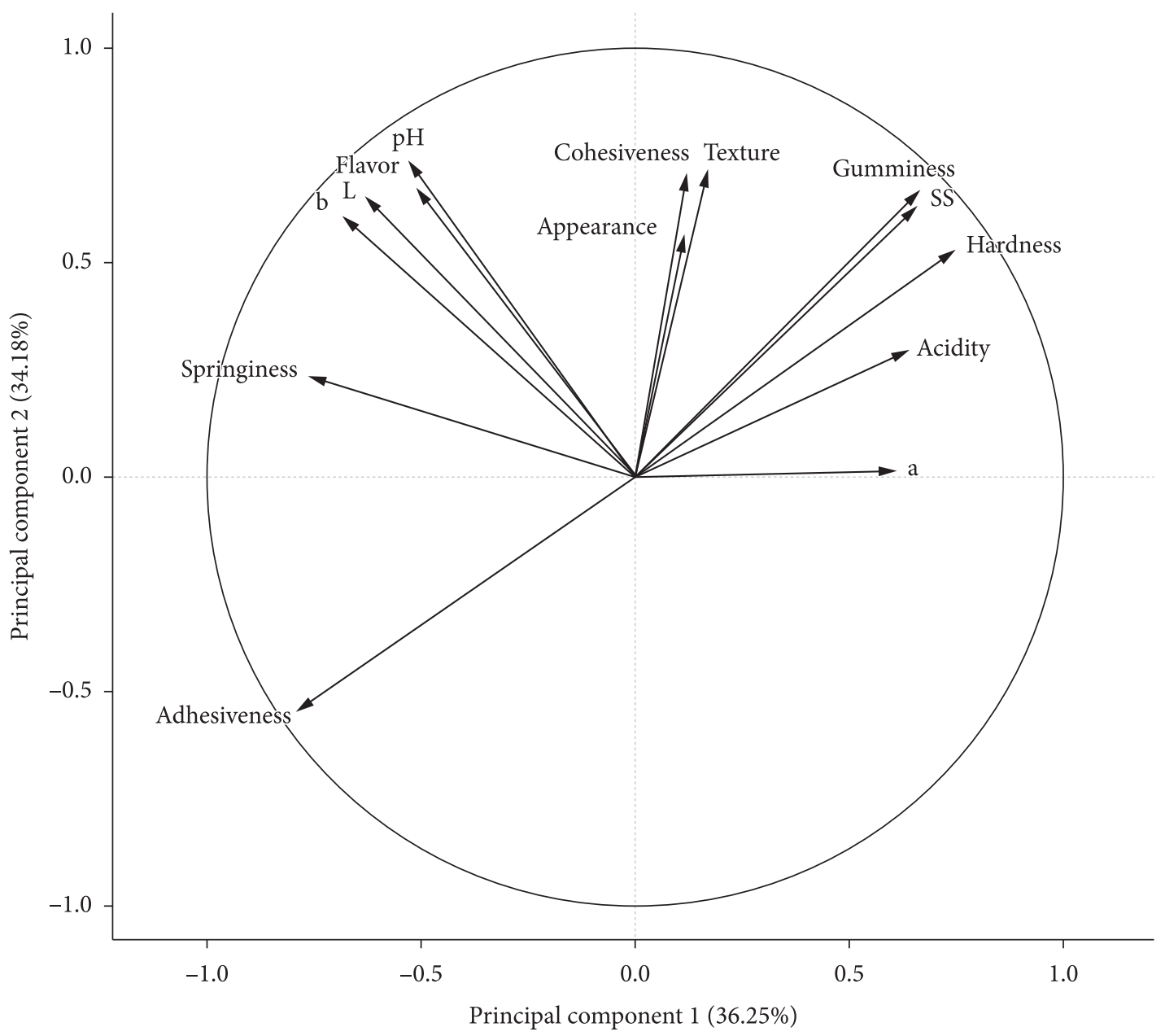

Figure 4. Circle correlation of data of the global impression with the results of sensory, physical and physicochemical analyses. 
These preference map (multivariate analysis) results agree with those obtained by the variance analysis (univariate analysis) and by the average test, in which samples 1 (10\% whey and $1 \%$ coffee) and 2 (30\% whey and $1 \%$ coffee), followed by $9(20 \%$ whey and $1.25 \%$ coffee), presented higher acceptance values.

\section{Conclusions}

The response surface methodology, by itself, was not enough to find the best formulation for the elaboration of the "dulce de leche" with coffee. From the test of averages and preference map, it was observed that the favorite consumers' formulations were samples 1 ( $10 \%$ whey and $1 \%$ coffee), 2 (30\% whey and $1 \%$ coffee), and 9 (20\% whey and $1.25 \%$ coffee) and the samples that presented the lowest acceptance were samples 5 (5.9\% whey and $1.25 \%$ coffee) and 8 (20\% whey and $1.6 \%$ coffee). In general, the "dulce de leche" with coffee and whey showed good sensory acceptance, and a decisive factor in the choice of formulations was the concentration of coffee because the consumers preferred the samples with low concentrations of coffee independent of the whey concentration, enabling with this the use of whey and the coffee in the manufacture of dulce de leche, thus obtaining a new product.

\section{Acknowledgements}

The authors acknowledge the fellowship provided by Coordenação de Aperfeiçoamento de Pessoal de Nível Superior (CAPES) are grateful for the financial support provided by Fundação de Amparo à Pesquisa do Estado de Minas Gerais (FAPEMIG).

\section{References}

ALMEIDA, K. E.; BONASSI, I. A.; ROÇA, R.O. Características físico e químicas de bebidas lácteas. Ciência e Tecnologia de Alimentos, v. 21, p. 187-192, 2001.

ARES, G.; GIMÉNEZ, A. Influence of temperature on accelerated lactose crystallization in dulce. International Journal of Dairy Technology, v. 61, n. 3, p. 277-283, 2008. http://dx.doi.org/10.1111/ j.1471-0307.2008.00403.x

ARES, G.; GIMÉNEZ, A.; GÁMBARO, A. Instrumental methods to characterize nonoral texture of dulce de leche. Journal of Texture Studies, v. 37, p. 553-567, 2006. http://dx.doi.org/10.1111/j.17454603.2006.00068.x

BARROS NETO, B.; SCARMINIO, I. S.; BRUNS, R. E. Planejamento e otimização de experimentos. 2. ed. Campinas: UNICAMP, 1995.

BANZATTO, D. A.; KRONKA, S. N. Experimentação agrícola. 4. ed. Jaboticabal: FUNEP, 2006.

BEHRENS, J. H.; SILVA, M. A. A. P.; WAKELING, I. N. Avaliação da aceitação de vinhos brancos varietais brasileiros através de testes sensoriais afetivos e técnica multivariada de mapa de preferência interno. Ciência e Tecnologia de Alimentos, v. 19, n. 2, p. 214220, 1999.

DIAS, C. A.; CORRENTE, L. A.; DIAS, C. A. Análise sensorial de doce de leite produzido com adição de soro de leite. In: SEMANA DE TECNOLOGIA EM ALIMENTOS, 6., 2008, Ponta Grossa, Paraná. Anais... Ponta Grossa, 2008.

FERREIRA, D. F. Análise estatística por meio do SISVAR para Windows, versão 4.0. In: REUNIÃO ANUAL DA REGIÃO BRASILEIRA DA SOCIEDADE INTERNACIONAL DE BIOMETRIA, 45., 2000, São Carlos. Anais... São Carlos, 2000.
GIMÉNEZ, A.; ARES, G.; GÁMBARO, A. Consumer perception of sandiness in dulce de leche. Journal of Sensory Studies, v. 23, p. 171185, 2008a. http://dx.doi.org/10.1111/j.1745-459X.2007.00148.x

GIMÉNEZ, A.; ARES, G.; GÁMBARO, A. Consumer reaction to changes in sensory profile of dulce de leche due to lactose hydrolysis. International Dairy Journal, v. 18, p. 951-955, 2008b. http://dx.doi. org/10.1016/j.idairyj.2007.12.007

GIRALDO-ZUÑIGA, A. D. et al. Propriedades funcionais e nutricionais das proteínas do soro de leite. Revista do Instituto de Laticínios Cândido Tostes, v. 57, n. 325, p. 35-46, 2002.

INSTITUTO ADOLFO LUTZ - IAL. Normas Analíticas do Instituto Adolfo Lutz: métodos químicos e físicos para análise de alimentos. 3. ed. São Paulo: IAL, 1985.

MACHADO, L. M. P. Uso do soro de queijo e amido de milho modificado na qualidade do doce de leite pastoso. 2005. $170 \mathrm{f}$. Tese (Doutorado em Tecnologia de Alimentos)-Faculdade de Engenharia de Alimentos, Universidade Estadual de Campinas, Campinas, 2005.

MADRONA, G. S. et al. Estudo do efeito da adição de soro de queijo na qualidade sensorial do doce de leite pastoso. Ciência e Tecnologia de Alimentos, v. 29, n. 4, p. 826-833, 2009

MARKETO, C. G. et al. The reliability of mdpref to show individual preference. Journal of Sensory Studies, v. 9, n. 3, p. 337-359, 1994. http://dx.doi.org/10.1111/j.1745-459X.1994.tb00251.x

MARTINS, J. F. P.; LOPES, C. N. Doce de leite: aspectos da tecnologia de fabricação. Campinas: Instituto de Tecnologia de Alimentos, 1981. p. 1-37. (Instruções técnicas, n. 18).

MINIM, V. P. R. Análise sensorial: estudos com consumidores. Viçosa: UFV, 2006.

MORR, C. V.; HA, Y. W. Whey protein concentrates and isolates: processing and functional properties. Critical Reviews in Food Science and Nutrition, v. 33, n. 6, p. 431-476, 1993. PMid:8216810. http://dx.doi.org/10.1080/10408399309527643

MOSKOWITZ, H. R. Product optimization approaches and applications. In: MAC FIE, H. J. H.; THOMPSON, D. M. H. Measurement of food preferences. Glasgow: Blackie Academie \& Professional, 1994. chap. 4, p. 97-136.

PEREIRA, D. B. C. et al. Físico-química do leite e derivados: métodos analíticos. 2. ed. Juiz de Fora: Oficina de Impressão, 2000.

R DEVELOPMENT CORE TEAM. R: a language and environment for statistical computing. Vienna: R Foundation for Statistical Computing, 2007. Disponível em: <http//www.R-project.org >. Acesso em: 19 ago. 2009.

REIS, R. C. et al. Mapa de preferência. In: MINIM, V. P. R. Análise sensorial: estudo com consumidores. Viçosa: UFV, 2006. cap. 5, p. 111-126.

SCHLICH, P. Preference mapping: relating consumer preferences to sensory or instrumental measurements. In: ETIEVANT, P. SHREIER, P. Bioflavour 95: analysis/precursor studies/biotechnology. 2. ed. Orlando: Flórida Academic, 1995.

SILVA, K.; BOLINI, H.M.A. Avaliação sensorial de sorvete formulado com produto de soro ácido de leite bovino. Ciência e Tecnologia de Alimentos, v.26, n. 1, p. 116-122, 2006.

STATSOFT SOFTWARE. Statistic for Windows: versão 5.0. Tulsa: Statsoft, 1995. Disponível em: <www.statsoft.com>. Acesso em: 20 ago. 2009.

STONE, H. S.; SIDEL, J. L. Sensory evaluation practices. San Diego: Academic, 1993.

WAKELING, I. N.; MAC FIE, H. J.H. Designing consumer trials balanced for first And higher orders of carry-over effect when only a subset of $k$ samples from $t$ may be tested. Food Quality and Preference, v. 6, n. 4, p. 299-308, 1995. http://dx.doi.org/10.1016/0950-3293(95)00032-1 